Western North American Naturalist 67(4), (C) 2007, pp. 611-612

\title{
THERE IS NO VALID RECORD OF CLIFF CHIPMUNK (TAMIAS DORSALIS) IN THE SANDIA MOUNTAINS, NEW MEXICO
}

\author{
Jennifer K. Frey ${ }^{1}$
}

\begin{abstract}
A report of the cliff chipmunk (Tamias dorsalis) from the Sandia Mountains, New Mexico, was erroneous. The capture location of the specimen was actually the Rio Puerco drainage in Sandoval County. There are no records of the cliff chipmunk from the Sandia Mountains or elsewhere east of the Rio Grande.

Key words: Tamias dorsalis, cliff chipmunk, distribution, Sandia Mountains, New Mexico.
\end{abstract}

Accurate distributional data are necessary for understanding basic features of a species' biology, such as its evolutionary history, ecology, biogeography, habitat relations, and interrelations with other species. This may be particularly true for species that occupy insular habitats, such as mountaintop islands of conifer habitat in the western USA, because analyses of these distribution patterns are used to study processes of species assemblage and diversity (e.g., MacArthur and Wilson 1967, Brown 1971, McDonald and Brown 1992, Frey et al. 2007). Further, information about historical distribution patterns can provide key evidence needed to document recent extinction events and other changes in species distribution patterns (e.g., Frey 1992, Newmark 1995).

The cliff chipmunk (Tamias dorsalis) is broadly distributed throughout the Great Basin, southwestern USA, and northern Mexico, typically in association with coniferous woodlands dominated by pinyon pine (Pinus spp.) and juniper (Juniperus spp.; Hall 1981, Hart 1992). In New Mexico, the species occurs broadly throughout mid- to high-elevation mesas and mountains west of the Rio Grande, exclusive of the Rocky Mountains (i.e., San Juan and Jemez ranges; Findley et al. 1975, Frey 2004). However, Findley et al. (1975:107) reported examining a specimen of $T$. dorsalis in the Harvard University Museum of Comparative Zoology (MCZ) from Bernalillo County, "Sandia Mts., Armijo Lake," which represents the only record of the species from east of the Rio Grande in New Mexico. Findley et al. (1975: 107) further stated: "The single record of $E$. dorsalis from the Sandia Mountains was collected by Barber in 1901 (Barber 1902). Repeated collecting in these highly accessible mountains has revealed no others, and we would be tempted to suspect an error, except that Eutamias minimus and Microtus mexicanus both escaped detection in the Sandias for many years, and it must certainly be evident that even intensive collecting does not reveal every faunal element." Indeed, there have been no subsequent reports or verified specimens of T. dorsalis from the Sandia Mountains or elsewhere east of the Rio Grande in New Mexico. Thus, if true, this record would suggest either an unusual introduction or, more likely, a recent extinction event of the species in this mountain range. However, herein I provide evidence indicating that the record of the cliff chipmunk (Tamias dorsalis) from the Sandia Mountains was erroneous.

I examined the specimen (MCZ 10528) on which the Sandia Mountains record was based. Pelage features clearly identified the specimen as $T$. dorsalis, which is unique in having a gray back, a thin black median dorsal stripe, and dark and light lateral stripes so faint as to be nearly obscured (Howell 1929, Hall 1981, Hart 1992). The skin closely resembled other specimens of $T$. dorsalis from New Mexico. The skin bears 2 tags, including an original field tag and a museum tag, which was presumably added subsequent to the original tag. Data on the original tag includes (1) the location "Armijo Lake Bernalillo Co. N.M.", (2) the collector "Barber" (field number "2"), (3) the date "April 24 1901," and (4) measurements of

\footnotetext{
${ }^{1}$ Department of Fishery and Wildlife Sciences and The Vertebrate Museum, Department of Biology, Box 30003, Campus Box 4901, New Mexico State University, Las Cruces, NM 88003-8003. E-mail: jfrey@nmsu.edu
} 
"L. 8 1/8 in.," "3 1/2," and " $11 / 4$." The front of the museum tag is printed with "Museum Comp. Zoöl., Skin \& Skull No.” and bears the number "10528"; also included on the tag is "N. Mex. [space] Lake, Bernalillo Co, Apr. 24, 1901." The back of the museum tag includes “206.4-88.90-31.7," “C. M. Barber," and "Original No. 2." Thus, I found no reference to the Sandia Mountains on either tag. Further, Barber (1902), the paper referenced by Findley et al. (1975) as stating that the specimen was collected in the Sandia Mountains, made no reference to T. dorsalis or any other species of chipmunk. I have found no other papers by C.M. Barber or other authors that make reference to the provenance of this specimen.

The MCZ has no field notes for Barber that could be used to determine the collection location. However, the USGS Geographic Names Information System includes 1 listing for "Armijo Lake" in New Mexico, and it was located in Sandoval County, 35.4233674N, 106.9269817W (USGS 2006). During 1901, the year the specimen was collected, the boundaries of Bernalillo County included all of what is now Sandoval County (Coan 1965). Armijo Lake is a dry lakebed located in the Rio Puerco drainage ca. $13.7 \mathrm{~km} \mathrm{~N}, 34 \mathrm{~km} \mathrm{~W}$ Bernalillo, which is on the west side of the Rio Grande and ca. $48 \mathrm{~km}$ west-northwest of Sandia Peak. Other Barber specimens included a rock squirrel (Spermophilus variegatus; MCZ 10521) collected on 30 April 1901 from Cabezon, which is a settlement in western Sandoval County ca. $27 \mathrm{~km}$ northwest of Armijo Lake. Barber did collect specimens from the Sandia Mountains in 1901, but these were all later in the year, during July and August. Bailey (1931) previously reported T. dorsalis from 2 other locations within the Rio Puerco drainage, both above and below Armijo Lake. Thus, there is no evidence for the occurrence of $T$. dorsalis in the Sandia Mountains or elsewhere east of the Rio Grande in New Mexico.

I thank J. Chupasko and Mark Omura of the Harvard University Museum of Compara- tive Zoology for the loan of the specimen, J. Dunnum of the Museum of Southwestern Biology, University of New Mexico, for information on specimens in that collection, and $\mathrm{T}$. Frey for reviewing a previous version of this paper.

\section{Literature Cited}

BaIley, V. 1931 (=1932). Mammals of New Mexico. North American Fauna 53:1-412.

Barber, C.M. 1902. Notes on little-known New Mexican mammals and species apparently not recorded from the territory. Proceedings of the Biological Society of Washington 15:191-193.

Brown, J.H. 1971. Mammals on mountaintops: nonequilibrium insular biogeography. American Naturalist 105:467-478.

COAN, C.F. 1965. The county boundaries of New Mexico. New Mexico Legislative Council Services, Santa Fe. 27 pp.

Findley, J.S., A.H. Harris, D.E. Wilson, and C. Jones. 1975. Mammals of New Mexico. University of New Mexico Press, Albuquerque. 360 pp.

FreY, J.K. 1992. Response of a mammalian faunal element to climatic changes. Journal of Mammalogy 73:43-50. 2004. Taxonomy and distribution of the mammals of New Mexico: an annotated checklist. Occasional Papers, Museum of Texas Tech University 240:1-31.

Frey, J.K., M.A. Bogan, AND T.L. YATES. 2007. Mountaintop island age determines species richness of boreal mammals in the American Southwest. Ecography 30:231-240.

HaLl, E.R. 1981. The mammals of North America. John Wiley \& Sons, Inc., New York. 1181 pp.

Hart, E.B. 1992. Tamias dorsalis. Mammalian Species 399:1-6.

HowelL, A.H. 1929. Revision of the American chipmunks (Genera Tamias and Eutamias). North American Fauna 52:1-157.

MacArthur, R.H., And E.O. Wilson. 1967. The theory of island biogeography. Princeton University Press, Princeton, NJ. 203 pp.

McDonald, K.A., AND J.H. Brown. 1992. Using montane mammals to model extinctions due to global change. Conservation Biology 6:409-415.

NEWMaRK, W.D. 1995. Extinction of mammal populations in western North American national parks. Conservation Biology 9:512-526.

[USGS] United States Geological Survey. 2006. U.S. Board on Geographic Names [cited 10 April 2007]. Available from: http://geonames.usgs.gov/index.html

Received 11 April 2007 Accepted 1 June 2007 